\title{
Treatment of KNEE OSTEOARTHRITIS in Spa Health resorts: where do we stand?
}

\author{
Amalia Salca1, Nicoleta Stoica $^{1}$, Gabriela Dogaru' ${ }^{1,2}$ \\ 1. Clinical Rehabilitation Hospital Cluj-Napoca \\ 2. "Iuliu Hatieganu" UMPh Cluj-Napoca
}

\begin{abstract}
Osteoarthrosis (OA) includes degenerative joint disorders that affect articular cartilage in the first instance, followed by changes of all components of the joint. The disease is detected in a proportion of $33 \%$ by X-ray in patients aged over 60 years. Knee OA (KOA) ranks first among chronic diseases from the point of view of patient disability.

This article is a review of guidelines and articles regarding arthrosis, balneotherapy, and balneotherapy in KOA treatment. These were accessed on the Pubmed site in the period March-April 2015.

The components of balneo-therapy to which the selected articles refer include mud packs, mineral waters, climate change. These are evaluated in association or in comparison with other methods used in the rehabilitation specialty area for the treatment of KOA: kinesitherapy, intra-articular infiltrations, hydrothermotherapy.

The changes induced by these therapies on clinical evolution (pain relief, tenderness, functionality, quality of life, depression symptoms) or certain serum parameters (biomarkers of oxidative stress, inflammation and cartilage destruction, vitamin D and other serum metabolites) were recorded.

The results of our review are consistent with the studies focused on spa modalities in all types of OA. All these data helped defining the role of balneotherapy as part of the rehabilitation program for the treatment of KOA, through the benefits specific to it.

Conclusion: Balneotherapy has beneficial effects on patients with KOA, both clinically and serologic improvements. Further studies are needed to quantify these effects using KOA specific markers, to establish a hierarchy of balneotherapy methods based on their effects on KOA, as well as to refine indications depending on the stage of the disease.
\end{abstract}

\section{Introduction}

Balneology represents the branch that uses natural physical factors characteristic for spas, such as mineral waters, therapeutic muds (peloids) ${ }^{1}$. Balneotherapy has been defined recently as the use of natural mineral waters, natural peloids and mud, and natural sources of different gases $\left(\mathrm{CO}_{2}, \mathrm{H}_{2} \mathrm{~S}\right.$, and $\left.\mathrm{Rn}\right)$ for medical purposes such as prevention, treatment, and rehabilitation ${ }^{2}$.

Ostheoartrithis (OA) is the most frequent rheumathological degenerative disease. Within this pathology, the knee is the

main affected joint in all populations throughout the world ${ }^{3}$.
Osteoarthritis includes degenerative joint disorders that affect articular cartilage in the first instance, followed by changes of all components of the joint. The disease is detected in a proportion of $33 \%$ by X-ray in patient saged over 60 years. Knee osteoarthritis ranks first among chronic diseases in terms of patient disability.

There are numerous studies on balneotherapy for knee OA in the literature, but they are on a small scale ${ }^{4}$. Therefore in this field there is a lack of high quality scientific evidence of the efficacy for knee OA. In a recent Cochrane systematic review, even those studies that met the selection criteria were found to be flawed.

It is worth to be mentioned that balneotherapy is disregarded by most clinical guidelines from other specialties: for exemple it 
was not included in the 2013 EULAR recommendations ${ }^{5}$.

This article tries to answer the following questions: "does balneotherapy have good effects on KOA?", "is it used worldwide?", "is it worth to highlight its potential benefits through large clinical trials?".

\section{Materials and methods}

Our objective was to make a review of the current guidelines and articles regarding clinical and para-clinical effects of balneotherapy in kneeosteoarthritis. These were accessed on the Pubmed site in the period March-April 2015.

\section{Data extraction}

This review covers the use of thermal mineral waters, mud pack within balneo-therapy means used in KOA. Other rehabilitation intervention which were either associated with balneo-therapy or used as a term of comparison are: aerobic, muscle strengthening and waterbased exercise, intra-articular injections with Hyalgan. We searched the above-mentioned literature published between 2010 and 2014, using the following terms of search on Pubmed database: balneo-therapy, spa therapy, thermal water, mineral water, peloid, mud pack, hydrotherapy.

Regarding the inclusion criteria for reviewed articles, we included all clinical trials in the systematic review that assessed the effects of different balneotherapy procedures on clinical outcome, quality of life. Studies meeting the following criteria were selected for diagnose of KOA.

The randomized controlled trials comparing balneo-therapy with any intervention were also included.

\section{Results}

We found relevant 3 reviews and metaanalyses regarding the effect evaluation in spa modalities applied for KOA. 11 studies regard: the effects of mineral water and/ or mud pack therapy on clinical status and biological markers. And 1 study compares mud pack with intraarticular hyaluronic acid.

\section{Treatment effectiveness evaluation}

To evaluate the clinical status and the effects of balneo-therapy, the studies considered Visual Analogue Scale for spontaneous pain or WOMAC pain scale, WOMAC functional capacity, Psychosocial status, Depression, WOMAC osteoarthritis index, Hospital for Special Surgery (HSS) score, Knee Society clinical rating system (knee and function scores), Lequesne Index, WOMAC Index, SF-36, Arthritis Impact Measurement Scale (AIMS), Nottingham Health Profile (NHP) symptomatic drugs consumption. Some studies focused on plasmatic cartilage destruction markers, inflammatory mediators and other serum metabolites.

\section{Meta-analysis with balneo-therapy in KOA patients}

Françon A, Forestier R 2009 ${ }^{4}$, EspejoAntúnez L 2012 ${ }^{6}$, Hua Liu $2013^{7}$, as a result of the meta-analysis, consider the balneo-therapy effective on KOA, because of persistent reducing pain, improvement of functional capacity, improvement in quality of life, reducing analgesic and non-steroidal antiinflamatory drug consumption $^{4}$. Mud pack therapy is consider an effective therapy, reducing pain, improving function and quality of life ${ }^{6,7}$. 
Table 1. Meta-analysis balneo-therapy in KOA patients

Françon A, Forestier R 2009: Clinical practice guidelines published by the French National Authority for Health (HAS) and the European League Against Rheumatism (EULAR) and on the results of randomized clinical trials (RCT):

Sixteen studies indicated a persistent improvement (at least twelve weeks) in pain, analgesic and nonsteroidal antiinflammatory drug consumption, functional capacity and/or quality of life, in the following indications: chronic lower back pain, knee osteoarthritis, hand osteoarthritis, fibromyalgia, ankylosing spondylitis, rheumatoid arthritis (PR).

Espejo-Antúnez L, 20126\%: randomized clinical trials, systematic reviews or meta-analyses whose objective was to analyse the effect of mud pack therapy on perceived pain, function and quality of life, with a sample size of $\geq 20$ subjects, published since 2000 and showing conclusive results: mud pack therapy is considered alternative and effective therapy in the clinical management of knee OA.

Hua Liu, 20137 : A quantitative meta-analysis of seven studies- randomized controlled trials and prospective comparative studies published before 9 March 2013 that compared mud therapy with control group treatments in patients with knee OA (410 patients). There was a significant difference between the groups in the visual analogue scale pain score and Western Ontario and McMaster Universities Osteoarthritis Index pain score, with differences in favour of mud therapy.

\section{Clinical studies evaluating the effects of mineral waters and mud pack on pain and function in KOA patients}

We consider separately mineral water and mud pack studies in Table nr. 2 and Table nr. 3, whereas in Table nr. 4 we present a study that applied these procedures simultaneously.

Thermal mineral water baths resulted in significant improvement of the clinical status, reducing pain [measured with a visual analogue scale (VAS) or tenderness score (TS)], function [rated with the Western Ontario and McMaster Universities (WOMAC) scale, 50-ft walking duration, quadriceps muscle strength (QMS), active flexion degree (AFD), Nottingham Health Profile (NHP), Lequesne index of osteoarthritis severity] and quality of life [SF-36 quality of health questionnaire] after balneo-therapy; as seen in studies listed in Table nr. 2.

All 4 studies concluded that the hydrothermal treatment modalities, using spa water or tap water were found to be effective in the management of the clinical symptoms and quality of life in KOA patients. However, pain and tenderness improved statistically better with balneo-therapy. There were no significant differences between the groups for the other variables, like walking duration, quadriceps muscle strength, active flexion degree. Intermittent balneo-therapy appears to be effective for patients with knee osteoarthritis ${ }^{8,9}$. Positive effect on gait and improvement of clinical parameters have been obtained with balneo-therapy in short-term evaluations (2 weeks) ${ }^{10}$. Also, we found one clinical study ${ }^{11}$ demonstrating that the beneficial effects of balneo-therapy in patients with knee OA last over time (12 weeks), with positive effects on the painful symptomatology, a significant improvement on functional capacities and quality of life; the conclusion was that balneo-therapy can represent a useful backup to pharmacological treatment of knee OA or a valid alternative for patients who do not tolerate pharmacological treatments ${ }^{11}$.

The above mentioned studies have been conducted in countries such as Italy, Israel, Turkey. 
Table 2. Clinical studies evaluating the effects of mineral waters on pain and function in KOA patients

\begin{tabular}{|c|c|c|c|c|}
\hline Study & Treatment & $\begin{array}{l}\text { Outcome } \\
\text { measures }\end{array}$ & $\begin{array}{l}\text { Follow-up } \\
\text { period }\end{array}$ & Results \\
\hline $\begin{array}{l}\text { Yurtkuran M } \\
\text { al, } 2006^{8}\end{array}$ & $\begin{array}{l}52 \text { patients with KOA } \\
\text { home-based } \\
\text { standardized exercise } \\
\text { program and: group I } \\
(\mathrm{n}=27) \text { spa water at } \\
37 \text { degrees } \mathrm{C}, 20 \text { min } \\
\text { day, } 5 \text { days a week, } 2 \\
\text { weeks. group II ( } \mathrm{n}= \\
\text { 25), TW heated to } 37 \\
\text { degrees } \mathrm{C} \text {, the same } \\
\text { protocol . }\end{array}$ & $\begin{array}{l}\text { pain (pVAS), } \\
\text { tenderness score (TS), } \\
50 \text {-ft walking duration, } \\
\text { quadriceps muscle strength } \\
\text { (QMS), active flexion degree } \\
\text { (AFD), WOMAC OA index, } \\
\text { Nottingham Health Profile (NHI }\end{array}$ & $\begin{array}{l}\text { 2nd and } 12 \\
\text { week }\end{array}$ & $\begin{array}{l}\text { Pain and tenderness } \\
\text { improved better with } \\
\text { balneo-therapy. } \\
\text { Hydrotherapy improves } \\
\text { clinical symptoms and } \\
\text { quality of life. }\end{array}$ \\
\hline $\begin{array}{l}\text { Sherman G } \\
2009^{9}\end{array}$ & $\begin{array}{l}\text { 44 KOA patients: a } \\
\text { treatment group } \\
(\mathrm{n}=24) \text {, treated twice } \\
\text { weekly for } 6 \\
\text { consecutive weeks in } \\
\text { sulfur pool heated to } \\
\text { 35-36 degrees C; } \\
\text { control group }(\mathrm{n}=20) \\
\text { treated in a Jacuzzi } \\
\text { filled with tap water } \\
\text { heated to } 35-36 \\
\text { degrees C. }\end{array}$ & $\begin{array}{l}\text { Lequesne index of osteoarthritis } \\
\text { severity, } \\
\text { WOMAC index, } \\
\text { SF-36 quality of health } \\
\text { questionnaire, } \\
\text { VAS scales for pain (completed } \\
\text { by patients and physicians), } \\
\text { physical examination. }\end{array}$ & 6 months & $\begin{array}{l}\text { Intermittent balneo- } \\
\text { therapy appears to be } \\
\text { effective for patients with } \\
\text { knee osteoarthritis }\end{array}$ \\
\hline $\begin{array}{l}\text { Kiliçoğlu O el } \\
\text { al, } 2009^{10}\end{array}$ & $\begin{array}{l}30 \text { KOA patients: two } \\
\text { daily thermomineral } \\
\text { water baths for } \\
2 \text { weeks. }\end{array}$ & $\begin{array}{l}\text { Gait analysis and clinical scores: } \\
\text { Lequesne knee osteoarthritis } \\
\text { index, VAS, investigator's globa } \\
\text { assessment, WOMAC score }\end{array}$ & 2 weeks & $\begin{array}{l}\text { Positive } \\
\text { effects on gait properties } \\
\text { and } \\
\text { clinical health quality } \\
\text { parameters. }\end{array}$ \\
\hline $\begin{array}{l}\text { Fioravanti } \\
2012^{11}\end{array}$ & $\begin{array}{l}60 \text { outpatients with } \\
\text { primary bilateral } \mathrm{KO} t \\
\text { group I ( } 30 \\
\text { patients)daily } \\
\text { sulphate-bicarbonate- } \\
\text { calcium mineral wates } \\
\text { bath; group II ( } 30 \\
\text { patients), the control } \\
\text { group, continued thei1 } \\
\text { regular outpatient car } \\
\text { routine. }\end{array}$ & $\begin{array}{l}\text { Visual Analogue Score(VAS) fo } \\
\text { spontaneous pain, } \\
\text { Lequesne Index } \\
\text { Womac Index } \\
\text { SF-36, } \\
\text { Arthritis Impact Measurement } \\
\text { Scale (AIMS) } \\
\text { symptomatic drugs consumption }\end{array}$ & $\begin{array}{l}15 \text { days } \\
12 \text { weeks }\end{array}$ & $\begin{array}{l}\text { Positive effects on the pain } \\
\text { a significant improvement } \\
\text { on functional capacities an } \\
\text { QoL }\end{array}$ \\
\hline
\end{tabular}

Mud pack is a favorable option compared with hot pack for pain relief and for the improvement of functional conditions in treating patients with knee osteoarthritis ${ }^{12}$. The mud-bath therapy performed at Chianciano Spa with
Sillene Spring water remarkably improved the clinical conditions of patients with knee arthritis and significantly reduces the frequency and severity of symptoms and the disability they cause $^{13}$. 
The tolerability is very good, no adverse effects were observed ${ }^{13}$.

Table 3. Clinical studies evaluating the effects of mud pack on pain and function in KOA patients

\begin{tabular}{|c|c|c|c|c|}
\hline Study & Treatment & $\begin{array}{l}\text { Outcome } \\
\text { measures }\end{array}$ & $\begin{array}{l}\text { Follow-up } \\
\text { period }\end{array}$ & Results \\
\hline $\begin{array}{l}\text { Fraioli A } \\
\text { al, 2010, Ita } \\
13\end{array}$ & $\begin{array}{l}61 \text { KOA patients: grour } \\
\text { A underwent three } \\
\text { cycles of mud-based sp } \\
\text { therapy over a year's } \\
\text { time, whereas group B } \\
\text { did not }\end{array}$ & $\begin{array}{l}\text { Clinical conditions, } \\
\text { Visual Analogue Scale } \\
\text { pain ratings, } \\
\text { Lequesne indexes }\end{array}$ & 1 year & $\begin{array}{l}\text { No adverse effects observe } \\
\text { in any of the patients } \\
\text { group A. Improvement } \\
\text { clinical conditions. } \\
\text { Increase the frequency an } \\
\text { severity of symptoms and } \\
\text { the disability. }\end{array}$ \\
\hline $\begin{array}{l}\text { Sarsan et } \\
2012^{12}\end{array}$ & $\begin{array}{l}27 \text { patients with clinical } \\
\text { and radiologic evidence } \\
\text { of knee osteoarthritis, } 2 \\
\text { groups: mature mud } \\
\text { packs (n 15) or hot pacl } \\
(\mathrm{n}=12) \text {. }\end{array}$ & $\begin{array}{l}\text { VAS, WOMAC, } 6 \text { min } \\
\text { walking distance, Short } \\
\text { Form-36 (SF-36), serum } \\
\text { levels of tumor necrosis } \\
\text { factor-alpha (TNF- } \alpha \text { ), } \\
\text { interleukin-6 (IL-6), } \\
\text { insulin-like growth factor } \\
1 \text { (IGF-1) }\end{array}$ & $\begin{array}{l}\text { post-treatment } \\
\text { and } 3 \text { and } \\
6 \sim \text { months afte } \\
\text { treatment }\end{array}$ & $\begin{array}{l}\text { Mud pack is a favorable } \\
\text { option compared with hot } \\
\text { pack for pain relief and fo } \\
\text { the improvement of } \\
\text { functional conditions in } \\
\text { treating patients with knee } \\
\text { osteoarthritis. }\end{array}$ \\
\hline
\end{tabular}

Combination of mineral waters and mudpack in treatment of KOA patient determined improvements on pain, range of motion, psychological status and quality of life ${ }^{14}$.

Table 4. Clinical study evaluating the effects of both mineral waters and mud pack on pain, function, psychological status in KOA patients

\begin{tabular}{|c|c|c|c|}
\hline Study & Treatment & $\begin{array}{l}\text { Outcome } \\
\text { measures }\end{array}$ & $\begin{array}{l}\text { Follow-up Results } \\
\text { period }\end{array}$ \\
\hline $\begin{array}{l}\text { M Constantir } \\
\text { et all, } 2011^{14}\end{array}$ & $\begin{array}{l}44 \text { KOA patients: muc } \\
\text { packs and bicarbonate } \\
\text { sulphurous mineral } \\
\text { bath water from Term } \\
\text { of TeleseSpA } \\
\text { (Benevento-Italy) }\end{array}$ & $\begin{array}{l}\text { Pain (VAS scale) } \\
\text { Degree of knee flexion (usir } \\
\text { goniometer) } \\
\text { Level of anxiety and depression } \\
\text { (SDS Zung Test and SAS Zung } \\
\text { test) } \\
\text { Quality of life (algofunction } \\
\text { Lequesne indice). }\end{array}$ & $\begin{array}{ll}\text { Baseline } & \text { Reduction of the pain, } \\
\text { End of } & \text { increase of the knee } \\
\text { treatment } & \text { flexion, quality of life } \\
& \text { improvement }\end{array}$ \\
\hline
\end{tabular}

\section{Mud pack therapy compared with intra- articular hyaluronic acid injections in KOA patients}

Bostan et al, 2010 ${ }^{15}$ compared the effectiveness of mud therapy with intra-articular hyaluronic acid injections in two clinical and radiological similar KOA patients. The conclusion is that treatment of knee osteoarthritis with intra-articular hyaluronic acid injections or mud-pack therapy yielded similar results in the short-term in terms of functional improvement and pain relief; that means to consider mud-pack therapy as a noninvasive, complication-free, and cost-effective alternative modality for the conservative treatment of knee osteoarthritis. 
Table 5. Mud pack therapy compared with intra-articular hyaluronic acid injections in KOA patients

\begin{tabular}{|c|c|c|c|c|}
\hline Study & Treatment & $\begin{array}{l}\text { Outcome } \\
\text { measures }\end{array}$ & $\begin{array}{l}\text { Follow-up } \\
\text { period }\end{array}$ & Results \\
\hline $\begin{array}{l}\begin{array}{l}\text { Bostan } \\
\text { al, }\end{array} \\
2010^{15}\end{array}$ & $\begin{array}{l}23 \text { KOA patients stag€ } \\
2 \text { or } 3 \text { (Kellgren- } \\
\text { Lawrence criteria): } 12 \\
\text { patients received mud } \\
\text { therapy bilaterally ( } 45 \\
\text { degrees C applied on } \\
\text { both knees for } 30 \\
\text { minutes daily for a tot; } \\
\text { of } 12 \text { weekdays); } 11 \\
\text { patients received a tot: } \\
\text { of three bilateral intra- } \\
\text { articular hyaluronic } \\
\text { acid injections, each } \\
\text { interspersed by weekl! } \\
\text { intervals. }\end{array}$ & $\begin{array}{l}\text { WOMAC osteoarthritis inde } \\
\text { Hospital for Special Surgery } \\
\text { (HSS) score, } \\
\text { Knee Society clinical rating } \\
\text { system (knee and function } \\
\text { scores) }\end{array}$ & $\begin{array}{l}\text { range } 4 \text { to } 8 \\
\text { months after } \\
\text { mud-pack } \\
\text { therapy, } \\
\text { range } 5 \text { to } 7 \\
\text { months after } \\
\text { intra-articular } \\
\text { hyaluronic aci } \\
\text { injections. }\end{array}$ & $\begin{array}{l}\text { Similar results in the } \\
\text { short-term in terms of } \\
\text { functional improvemen } \\
\text { and pain relief. }\end{array}$ \\
\hline
\end{tabular}

Balneo-therapy at the Dead Sea improves clinical status (pain, function, ADL) in KOA and the effect is sustained at least three months ${ }^{16}$.

\section{Balneo-therapy's effects on para-clinic parameters}

Regarding cartilage distruction, spa therapy can modify plasma levels of the adipocytokines, leptin and adiponectin, important mediators of cartilage metabolism ${ }^{17}$. Adipo-cytokine, including leptin and adiponectin, may play an important role in the pathophysiology of osteoarthritis. In skeletal joints, adiponectin may act as a proinflammatory agent and may be involved in matrix degradation. Leptin modulates the immune respons, affecting the bone and cartilage metabolism. Spa therapy decreases adiponectine levels, which means that balneotherapy may play a protective role in $\mathrm{OA}$.

Serum levels of tumor necrosis factoralpha (TNF- $\alpha$ ), interleukin-6 (IL-6), insulin-like growth factor-1 (IGF-1) B are known to increase in $\mathrm{OA}$, as they are inflammatory mediators. Other serology metabolites cited in the reviewed literature are: YKL-40 level in mud pack therapy, which seems to slow down the progression of knee OA C or Vitamin $\mathrm{D}^{18}$ significant changes after climate-therapy at the Dead Sea. Another study revealed reduction in oxidation, inflammation and cartilage degradation parameters ${ }^{19}$ in patients undergoing sulfur-based spa therapies for OA, including KOA.

On a study from 2012, Gungen et al ${ }^{20}$ demonstrated that mud pack and hot pack therapy were both effective in symptomatic treatment of knee OA until the end of the 2-week treatment period, whereas only mud pack therapy was shown to be effective in functional status over time (3 months). On the other hand, at baseline serum mean YKL-40 and hsCRP levels of the patients were higher compared to healthy control group. No significant change was observed in hsCRP levels in both groups during the whole follow-up periods. Maintenance of YKL-40 level in mud pack therapy seems to slow down the progression of knee OA.

Fioravanti et al, $2009^{17}$ published a randomized single-blind controlled clinical trial, with 30 patients (Spa Centre, RapolanoTerme) with 12 applications in 2 weeks, daily, mudpacks applied on both knees for $20 \mathrm{~min}$ at an initial temperature of $45 \mathrm{C}$ and bicarbonatesulphate mineral bath water at $38 \mathrm{C}$ for $15 \mathrm{~min}$. 
The authors found a slight, but not significant, increase in plasma leptin after 2 weeks of spa therapy, with no evident correlation with parameters of clinical efficacy (VAS, Lequesne Index). The decrease in adiponectin after spa therapy was found; this may play a protective role in OA. Spa therapy can modify plasma levels of the adipocytokines leptin and adiponectin. The authors consider that further studies on larger numbers of cases are needed to evaluate the effects of spa therapy on adipocytokines and the mechanisms with which said therapy may modify production thereof, as well as whether such modifications may have repercussions on cardiovascular risk factors.

\section{Clinical practice guidelines}

2013 EULAR recommendations(4) for the non-pharmacological core management of hip and knee osteoarthritis consist of eleven evidence-based recommendations for the nonpharmacological core management of hip and knee OA, concerning the following topics: assessment, general approach, patient information and education, lifestyle changes, exercise, weight loss, assistive technology and adaptations, footwear and work. 2013 EULAR recommendations don't include balneo-therapy, though Spa was listed among the treatment modalities identified by the EULAR for the management of knee OA in $2003^{21}$.

We mention the response of Dr. Romain J Forestier and F Begümto 2013 EULAR recommendations, given by, in which they sustain that balneo-therapy should be among the means of therapy studied by EULAR. Their arguments are the following: "We think that creno-balneo-therapy is a non-pharmacological treatment.", "We suggest that, since crenobalneo-therapy is a well evaluated treatment, these non-pharmacological treatment guidelines should also analyse this and some other trials published in this field." 22 .

OARSI 2008 (OA Research Society International) Recommendations ${ }^{23}$ for the management of hip and knee osteoarthritis cover the use of 12 non-pharmacological modalities: education and self-management, regular telephone contact, referral to a physical therapist, aerobic, muscle strengthening and water-based exercises, weight reduction, walking aids, knee braces, footwear and insoles, thermal modalities, transcutaneous electrical nerve stimulation and acupuncture.

OARSI $2014 \quad$ Recommendations ${ }^{24}$ consider balneo-therapy as appropriate only for the sub-phenotype with multiple-joint $\mathrm{OA}$ and co-morbidities, the last ones restricting the alternatives of treatment due to intrinsic contraindications. The authors conclude that additional large and well-designed RCTs are needed in this field, as it would be uncertain for individuals without relevant co-morbidities and individuals with knee-only OA. However, no significant safety issues were reported within balneo-therapy

Although it recommends an holistic approach of OA, the NICE clinical guidelines from $2014^{25}$ do not mention spa procedures among the therapeutic interventions. Furthermore it doesn't give any aspecific indications for the OA localized in the knee.

AAOS (American Academy of Orthopaedic Surgeons) Recommendations for KOA ("Treatment of Ostheoarthritis of the knee") $)^{26}$ are strong for self-management programs, strengthening and low-impact exercises, neuromuscular education, engagement in physical activity and NSAIDs (oral or topical) or Tramadol for symptomatic patients. There is also a moderate recommendation for weight loss. Other therapies, worldwide used in KOA, such as physical agents including electrotherapy, acupuncture, manual therapy, a medial compartment unloader, lateral wedge insoles, glucosamine and chondroitin, acetaminophen, opioids or pain patches, intra-articular corticosteroids of hyaluronic acid, growth factor injections and/or platelet rich plasma, needle lavage have the strength of recommendation ranging from moderate to inconclusive, or even not recommended (acupuncture, glucosamine, 
chondroitin and Hyaluronic acid injections). However, no references are made regarding spa modalities, whether or not they are indicated for KOA.

\section{Discussions}

Overall, the components of balneotherapy to which the selected articles refer include mudpacks, mineral waters (bicarbonatesulphate mineral bath water, Sulphur pool). These are compared or associated with other methods used in the rehabilitation specialty area for the treatment of kneeosteoarthritis: kinesitherapy, pharmacological therapy, biomecanical interventions, hydro / thermo therapy.

The psychological improvement (evaluated through the SDS Zung Test and SAS Zung Test for anxiety and depression level) was obtained by M. Constantino et al, $2011^{14}$ study, in which the authors report reduction of the pain, increase of the knee flexion and quality of life improvement in patients with KOA that underwent both mud packing as well as mineral waters. These data are consistent with spamodalities studies focused on generalised OA or affecting other joints, such as hip or spine. Ali Nasermoaddeli and Sadanobu Kagamimori mention a RCT conducted in Vichey (France) for a period of 3 weeks, which compares spa therapy with usual therapy performed at home. The group of patients had either hip, knee or lumbar spine OA. M. Constantino et al, $2011^{27}$ searched the effect of sulfurous mud and general bath in axial spondyloarthritis (99 patients), 36\% patients having KOA as an associated diagnose

Kinetotherapy, which means aerobic, muscle strengthening and water-based exercises ${ }^{23}$ in KOA therapy, has improvements in certain patients' parameters when associated to spa therapy. Thus the cited studies have proved a difference in clinical symptoms and quality of life in the groups that followed both procedures (kinetotherapy and spa therapy). Pharmacological therapy, like intra-articular injections with hyaluronates, compared to mud packs showed that the latter ones are a noninvasive, complication-free, and costeffective alternative modality ${ }^{15}$. Hidro-therapy with tap water is less effective, showing that mineral water improved better the pain (pVAS), tenderness score (TS) ${ }^{8}$.

Therefore, compared with other means of Physical Medicine, Spa therapy seems to have certain advantages. This is due to enhancement of good effects of regular in-patient and outpatient therapy routine. But the most important aspect are its specific characteristics such as: non-invasiveness, free of complications, costeffective.

Both EULAR 2003 and OARSI 2008 (OA Research Society International) list balneotherapy as means of treatment for KOA, under the terms of "SPA", respectively "Thermal modalities".

OARSI 2014 recommend balneo-therapy/spa therapy as appropriate for individuals with multiple-joint OA and relevant co-morbidities, more than that, it states that no significant safety events were found to be determined by balneotherapy. The above mentioned sub-phenotype of population would have an indication for balneotherapy due to paucity of treatment alternatives for that group.

Still, the presence of spa therapy is scarce in the guidelines issued for KOA therapy. 2013 EULAR recommendations, "2014 Nice clinical guidelines", AAOS (American Academy of Orthopaedic Surgeons) Recommendations for KOA ("Treatment of Ostheoarthritis of the knee") don't include balneo-therapy in the management of KOA /OA, but focus on education, lifestyle changes, weight loss. Since it is known that a small to moderate proportion of people with knee OA met physical activity guidelines and recommended daily $\operatorname{steps}^{28}$, balneologic resorts could be a friendly and relaxing environment, where patients could be educated, and closely guided in lifestyle changes. Thus helping in achieving the goals of all above mentioned guidelines.

Despite numerous small scale studies, there is a lack of high quality scientific evidence 
for the efficacy of spa therapy for knee osteoarthritis. Perhaps for this reason, spa therapy does not appear in the recommended treatments of the European League Against Rheumatism nor in the AAOS clinical practice guideline ("Treatment of Ostheoarthritis of the knee").

\section{Conclusions}

In conclusion, balneo-therapy is effective on clinical status in KOA patients, in terms of pain, function, quality of life, reducing analgetics and NSAIDs consumption, diminution of depression \& anxiety symptoms.

It is well known the good tolerability of spa therapy, and the hereby reviewed articles do not report any major adverse events associated with it. However, evidence-based and expert consensus guidelines need more evidence-based data to consider balneo-therapy among the means of KOA therapy. For this reason, properly designed, controlled, clinical trials are required in the field of spa/balneology modalities in KOA.

Our questions "does balneo-therapy have good effects on KOA?", "is it used worldwide?", "is it worth to highlight its potential benefits through large clinical trials?" have a indubitable answer: YES, but it is important to demonstrate these through larger studies.

Future challenges could be studies that quantify good effects using KOA specific markers, to establish a hierarchy of spa methods, as well as to refine indications depending on the stage of the disease.

\section{References}

1. Liviu Pop, Laszlo Irsay, Textbook of Physiotherapy, 2006, pag 22.

2. Gutenbrunner $\mathrm{C}$, Bender $\mathrm{T}$, Cantista $\mathrm{P}$, Karagülle Z. A proposal for a worldwide definition of health resort medicine, balneology, medical hydrology and climatology. Int $\mathbf{J}$ Biometeorol.2010; 54:495-507.

3. Fibel KH, Hillstrom HJ, Halpern BC. State-ofthe-Art management of knee osteoarthritis. World J Clin Cases. 2015 Feb 16; 3(2): 89-101.
Available

full-text

on: http://www.ncbi.nlm.nih.gov/pmc/articles/PMC 4317618/

4. R Forestier, H Desfour, J-M Tessier, A Françon, A Foote, CGenty, C Rolland, C-F Roques, J-L Bosson; Spa therapy in the treatment of knee osteoarthritis: a large randomized multicentre trial, Ann Rheum Dis 2010. 69: 660665.

5. EULAR recommendations for the nonpharmacological core management of hip and knee osteoarthritis, Current management of knee OA includes non-pharmacological and pharmacological treatments. Ann Rheum Dis.2013 Jul. 72(7): 1125-35. Available at: http://www.ncbi.nlm.nih.gov/pubmed/23595142 6. Luis Espejo-Antúnez1, María A. CarderoDurán, Elisa M. Garrido-Ardila, Silvia TorresPiles, Berta Caro-Puértolas; Clinical effectiveness of mud pack therapy in knee osteoarthritis, Oxford Journals, Medicine \& Health, Rheumatology, Volume 52, Issue 4, Pp. 659-668.

7. Hua Liu, Chao Zeng, Shu-guang_Gao, Tuo Yang Wei, Luo Yu-sheng, Li Yi-lin, Xiong Jinpeng, Sun Guang-hua Lei, The effect of mud therapy on pain relief in patients with knee osteoarthritis: A meta-analysis of randomized controlled trials, Journal of International Medical Research October 2013 vol. 41 no. 5 1418-1425; Available at: http://www.ncbi.nlm.nih.gov/pubmed/?term=Th e+effect+of+mud+

therapy+on+pain+relief+in+patients+with+knee +osteoarthritis\%3A+A+metaanalysis+of+randomized+controlled+trials

8. Yurtkuran M, Alp A, Nasircilar A, Bingol U, Altan L, Sarpdere G, Balneotherapy and tap water therapy in the treatment of knee osteoarthritis, RheumatolInt, 2006 Nov;27(1):19-27.

Available

at: http://www.ncbi.nlm.nih.gov/pubmed/16832639 9. Sherman G, Zeller L, Avriel A, Friger M, Harari M, Sukenik S., Intermittent balneotherapy at the Dead Sea area for patients with knee 
osteoarthritis, Isr Med Assoc J. 2009 Feb;11(2):88-93.

10. Önder Kılıçoğlu, Arif Dönmez, Zeki Karagülle, Nergis Erdoğan, Ekin Akalan, Yener Temelli, Effect of balneotherapy on temporospatial gait characteristics of patients with osteoarthritis of the knee, Rheumatology International, April 2010, Volume 30, Issue 6, pp 739-747

11. Antonella Fioravanti, Chiara Giannitti, Barbara Bellisai, Francesca Iacoponi, Mauro Galeazzi, Efficacy of balneotherapy on pain, function and quality of life in patients with osteoarthritis of the knee, International Journal of Biometeorology, July 2012, Volume 56, Issue 4, pp 583-590

12. Sarsan, Ayşe, Akkaya, Nuray, Özgen, Merih, Yildiz, Necmettin, Atalay, NilgunSimsir, Ardic, Fusun, Comparing the efficacy of mature mud pack and hot pack treatments for knee osteoarthritis, Journal of Back and Musculoskeletal Rehabilitation, vol. 25, no. 3, 2012.

13. Antonio Fraioli, Angelo Serio, Gioacchino Mennuni, Fulvia Ceccarelli, Luisa Petraccia, Mario Fontana, Marcello Grassi, Guido Valesini, A study on the efficacy of treatment with mud packs and baths with Sillene mineral water (Chianciano Spa Italy) in patients suffering from knee osteoarthritis, Rheumatology International , October 2011, Volume 31Issue 10, pp 1333-1340 14. Costantino M, Filippelli A. [Knee osteoarthritis and SPA therapy: assessment of joint function and quality of life]. Clin Ter. 2011; 162(2): e51-7. Available at: http://www.seuroma.it/riviste/clinica terapeutica/apps/autos.ph $\mathrm{p}$ ? id $=864$

15. Bostan B1, Sen U, Güneş T, Sahin SA, Sen C, Erdem M, Erkorkmaz U., Comparison of intra-articular hyaluronic acid injections and mud-pack therapy in the treatment of knee osteoarthritis., ActaOrthopTraumatolTurc. 2010; 44(1):42-7.

Available

at:

http://www.ncbi.nlm.nih.gov/pubmed/20513990
16. Sukenik $\mathrm{S}^{1}$, Flusser D, Codish S, Abu-Shakra M., Balneotherapy at the Dead Sea area for knee osteoarthritis. Isr Med Assoc J. 1999 Oct; $1(2): 83-5$.

17. Fioravanti A, Cantarini L, Bacarelli MR, de Lalla A, Ceccatelli L, Blardi P. Effects of spa therapy on serum leptin and adiponectin levels in patients with knee osteoarthritis. Rheumatol Int. 2011 Jul; 31(7): 879-82. Available at: http://www.ncbi.nlm.nih.gov/pubmed/?term=An tonella+Fioravanti+Effects +

of+Spa+therapy+on+serum+leptin+and+adipon ectin+levels+in+patients+with+knee+osteoarthri tis\%2C+Rheumatol+Int

18. Harari M, Dramsdahl E, Shany S, Baumfeld Y, Ingber A, Novack V, Sukenik S. Increased vitamin D serum levels correlate with clinical improvement of rheumatic diseases after Dead Sea climatotherapy. Isr Med Assoc J. 2011 Apr; 13 (4): 212-5.

19. Benedetti S, Canino C, Tonti G, Medda V, Calcaterra P, Nappi G, Salaffi F, Canestrari F. Biomarkers of oxidation, inflammation and cartilage degradation in osteoarthritis patients undergoing sulfur-based spa therapies. ClinBiochem. 2010 Aug; 43(12):973-8.

20. Gonca Gungen, FusunArdic, GulinFundikoglu, Simin Rota, The effect of mud pack therapy on serum YKL-40 and hsCRP levels in patients with knee osteoarthritis, Rheumatology International, May 2012, Volume 32, Issue 5, pp 1235-1244

21. Jordan KM, Arden NK, Doherty M, Bannwarth B, Bijlsma JW, Dieppe P, Gunther K, Hauselmann H, Herrero-Beaumont G, Kaklamanis P, Lohmander S, Leeb B, Lequesne M, Mazieres B, Martin-Mola E, Pavelka K, Pendleton A, Punzi L, Serni U, Swoboda B, Verbruggen G, Zimmerman-Gorska I, Dougados M; Standing Committee for International Clinical Studies Including Therapeutic Trials ESCISIT. EULAR Recommendations 2003: an evidence based approach to the management of knee osteoarthritis: Report of a Task Force of the Standing Committee for International Clinical 
Studies Including Therapeutic Trials (ESCISIT). Ann Rheum Dis. 2003 Dec; 62 (12):1145-55.

22. Forestier RJ, Erol FB. 'Is (creno) balneotherapy a drug, a surgical procedure or a non-pharmacological treatment?' eLetter on EULAR recommendations for the nonpharmacological core management of hip and knee osteoarthritis. Ann Rheum Dis. 2014 Feb; 73(2): e6.

23. Zhang W, Moskowitz RW, Nuki G, Abramson S, Altman RD, Arden N, BiermaZeinstra S, Brandt KD, Croft P, Doherty M, Dougados M, Hochberg M, Hunter DJ, KwohK,Lohmander LS, Tugwell P; “OARSI recommendations for the management of hip and knee osteoarthritis, Part II: OARSI evidencebased, expert consensus guidelines "; Osteoarthritis Cartilage. 2008 Feb; 16(2): 13762.

24. OARSI guidelines for the non-surgical management of knee osteoarthritis T.E. McAlindon, R.R. Bannuru, M.C. Sullivan, N.K. Arden, F. Berenbaum, S.M. Bierma-Zeinstra, G.A. Hawker, Y. Henrotin, D.J. Hunter, H. Kawaguchi, K. Kwoh, S. Lohmander, F. Rannou, E.M. Roos, M. Underwood Osteoarthritis and Cartilage Volume 22, Issue 3, Pages 363-388 (March 2014).

25. "Osteoarthritis: Care and management in adults"; NICE clinical guideline 177; February 2014. Available fulltext at: www.guidance.nice.org.uk/cg177

26. Hauk L. Treatment of knee osteoarthritis: a clinical practice guideline from the AAOS. Am Fam Physician. 2014 Jun 1; 89(11): 918-20. Available at: http://www.aafp.org/afp/2014/0601/p918.html 27. Nasermoaddeli A, Kagamimori S. Balneotherapy in medicine: A review. Environ Health Prev Med. 2005 Jul; 10(4):171-9. Fulltext available at:http://www.ncbi.nlm.nih.gov/pmc/articles/P MC2723310/

28. Maria Costantino, Amelia Filippelli, Patrice Quenau, Jean-Pierre Nicolas et Vittorio Coiro, "Rôle de l'eau minérale sulfurée dans la SPA thérapie de l'arthrose SulphurMineral Water and SPA Therapy in Osteoarthritis". Thérapie 2012 Janvier-Février; 67 (1): 43-48. Available at: http://www.journaltherapie.org/articles/therapie/abs/2012/01/th121 985/th121985.html

29. Luis EspejoAntúnez,a, Berta Caro Puértolas, Begonalbánez Burgos, José María Porto Payán, Silvia T. Torres Pilesa; "Effects of Mud Therapy on Perceived Pain and Quality of Life Related to Health in Patients With Knee Osteoarthritis"; Reumatol Clin. 2013; 9 (3): 156-160. 